\title{
ANALISIS PENERAPAN AKUNTANSI ZAKAT , INFAQ, SHODAQOH PADA BADAN AMIL ZAKAT NASIONAL (BAZNAS) PROVINSI JAWA BARAT
}

\author{
Mishelei Loen \\ Program Studi Akuntansi Fakultas Ekonomi \\ Universitas Krisnadwipayana \\ mishelei.loen@gmail.com
}

\begin{abstract}
The potential of zakat in Indonesia is currently around Rp 217 Trillion. Four times from the Ministry of Religion budget. Very big. However, one of the fundamental problems is the awareness of muzakki to fulfill zakat through zakat institutions is very small. The zakat institution in Indonesia is called the National Zakat Amil Agency (BAZNAS). The West Java Provincial Amil Zakat Agency has the main task of collecting, managing, distributing and empowering zakat, infaq, shadaqah funds, from all Muslims in West Java Province, based on the Zakat Act No.23 of the fifth part of article 29 paragraph 1 every year make annual reports as accountability. The accountability referred to in this case is the making of financial statements that are in accordance with the terms and conditions set out in the financial accounting standard PSAK 109 and are inseparable from sharia principles. The purpose of this study was to find out and apply PSAK109 regarding accounting for zakat infaq and almsgiving at the National Zakat Amil Agency (BAZNAS) of West Java Province. The method of analyzing the research conducted is descriptive qualitative analysis method. The results of this study indicate that the BAZNAS of West Java Province is in accordance with PSAK 109. However, the recognition of the burden of collection and distribution of zakat is not in accordance with PSAK 109.
\end{abstract}

Keywords: Zakat, Infaq, Shadaqah, PSAK109, Financial Statment 


\section{PENDAHULUAN}

Negara Indonesia merupakan Negara dengan jumlah penduduk muslim yang besar. Berdasarkan proyeksi Badan Perencanaan Pembangunan Nasional (Bappenas) 2013 jumlah penduduk Indonesia pada 2018 mencapai 265 juta jiwa. Jumlah tersebut terdiri dari 133,17 juta jiwa laki-laki dan 131,88 juta jiwa perempuan. Sekitar $87,13 \%$ dari total penduduk didominasi oleh penduduk muslim, yang belum dapat mengelola potensi zakat yang ada. Meski demikian, pengelolaan zakat tiap tahun mengalami kenaikan sekitar 35,84 \%. Potensi zakat di Indonesia saat ini sekitar Rp 217 Triliun. Empat kali dari anggaran Kementerian Agama. Sangat besar sekali. Meski demikian, salah satu problem mendasar adalah kesadaran muzakki untuk menunaikan zakat melalui institusi zakat sangat kecil. Mereka lebih senang berzakat secara tradisonal dan manual tanpa melalui lembaga zakat.

Lembaga zakat di Indonesia dinamakan Badan Amil Zakat Nasional (BAZNAS). Sementara itu, terjadi perkembangan yang menarik di Indonesia bahwa pengelolaan zakat, kini memasuki era baru, yakni dikeluarkannya Undang - undang yang berkaitan dengannya, yakni Undang - undang No. 38 tahun 1999 tentang pengelolaan zakat dengan Keputusan Menteri Agama (KMA) Nomor 581 tahun 1999 tentang Pelaksanaan Undang - Undang Nomor 38 tahun. Undang - undang tersebut menyiratkan tentang perlunya Badan Amil Zakat (BAZ) dan Lembaga Amil Zakat(LAZ) meningkatkan kinerja sehingga menjadi amil zakat yang profesional, amanah, terpercaya dan memiliki program kerja yang jelas dan terencana, sehingga mampu mengelola zakat, baik pengambilannya maupun pendistribusiannya dengan terarah yang kesemuanya itu dapat meningkatkan kualitas hidup dan kehidupan para mustahik.

Badan Amil Zakat (BAZ) dan Lembaga Amil Zakat (LAZ) merupakan salah satu entitas nirlaba, yang mengelola zakat, infaq dan Shodaqoh. Tujuan dibentuknya organisasi pengelola zakat, infaq dan Shodaqoh ini tidak lain untuk membatu sesama umat muslim dan juga sebagai salah satu sarana ibadah untuk lebih mendekatkan diri kepada Tuhan. Badan Amil Zakat (BAZ) dan Lembaga Amil Zakat (LAZ) di Indonesia menggunakan PSAK No. 45 tentang
Pelaporan Keuangan Organisasi Nirlaba, namun seiring dengan kemajuan zaman dan tuntutan untuk segera memiliki suatu standar yang baku dalam pelaporan, maka Forum Zakat bersama dengan Ikatan Akuntan Indonesia (IAI) menyusun akutansi zakat pada tahun 2007. Pada tahun 2008 IAI menyelesaikan PSAK No.109 tentang Akuntansi Zakat. Ikatan Akuntan Indonesia (IAI) sebagai wadah akuntan di Indonesia sejak tahun 2008 telah membuat Exposure Draft Pernyataan Standar Akuntansi Keuangan (ED PSAK) No. 109 Akuntansi Zakat, Infaq dan Shodaqoh. ED PSAK No. 109 Akuntansi Zakat, Infaq dan Shodaqoh dibuat dengan tujuan menyamakan bentuk laporan transaksi zakat infaq dan Shodaqoh yang semakin komplek. Dengan menyamakan bentuk laporan keuangan organisasi pengelola zakat, infaq dan Shodaqoh maka akan lebih mudah dalam mengauditnya.

Pada tahun 2010 tepatnya tanggal 6 April PSAK 109 Akuntansi Zakat, Infaq dan Shodaqoh telah disahkan dan dinikmati publik pada oktober 2011. Tujuannya adalah untuk memenuhi tuntutan masyarakat dalam menjalankan syariah Islam dan untuk meningkatkan keseragaman laporan keuangan pada Badan Amil Zakat (BAZ) atau Lembaga Amil Zakat (LAZ) di Indonesia sekaligus untuk memenuhi tuntutan dan ketentuan Good Governance yang meliputi transparency, responsibility, accountability, fairness dan indpendecy Utomo, (2007 : 14).

Badan Amil Zakat Nasional (BAZNAS) Provinsi Jawa Barat yang pada awalnya bernama Badan Amil Zakat (BAZ) Provinsi Jawa Barat ini didasarkan pada Keputusan Gubernur Jawa Barat tentang BAZ yang pertama kali didirikan pada tahun 1974. Kemudian setelah itu diperbaharui dengan Keputusan Menteri Agama Republik Indonesia Nomor 118 tahun 2014 tentang Pembentukan Badan Amil Zakat Nasional Provinsi. Kemudian, keputusan tersebut diperbarui kembali dengan Keputusan Menteri Agama RI Nomor 186 tahun 2016 tentang Perubahan atas Keputusan Menteri Agama Nomor 118 tahun 2014 tentang pembentukan Badan Amil Zakat Nasional Provinsi.

Badan Amil Zakat Nasional Provinsi memiliki tugas pokok mengumpulkan, mengelola, menyalurkan, dan memberdayakan dana zakat, infak, shadaqah, dari seluruh umat 
Islam di Provinsi Jawa Barat, berdasarkan UU Zakat No.23 Tahun 2011 bagian Kelima pasal 29 ayat 1 setiap tahunnya membuat laporan tahunan sebagai pertanggung jawaban. Pertanggungjawaban yang dimaksud dalam hal ini adalah pembuatan laporan keuangan yang sesuai dengan syarat dan ketentuan yang telah diatur dalam standar akuntansi keuangan PSAK No 109 serta tidak terlepas dari prinsip-prinsip syariah. Laporan tahunan ini terdiri dari laporan keuangan (Neraca, Laporan Sumber dan Penggunaan Dana, Laporan Arus Kas, Catatan atas laporan keuangan).

Dalam penerapan PSAK 109 tidak semua Badan Amil Zakat (BAZ) atau Lembaga Amil Zakat (LAZ) memahami pengaplikasian aturan tersebut pada proses pelaporan keuangannya. Diantara permasalah yang dominan muncul adalah pengakuan akuntansi dengan motode $c a s h$ basis, penggabungan dana zakat dan dana non zakat menjadi satu dalam pelaporan keuangannya, serta tidak dibuatnya laporan keuangan yang lengkap sesuai yang disyaratkan dalam PSAK, ketidakpahaman Badan Amil Zakat (BAZ) atau Lembaga Amil Zakat (LAZ) mengenai pembagian porsi dana zakat dan dana amil, dan bahkan terdapat Badan Amil Zakat (BAZ) atau Lembaga Amil Zakat (LAZ) yang belum memahami mengenai pelaporan keuangan yang wajib dipublikasikan Cahyadi, (2015).

Berdasarkan latar belakang diatas maka dapat ditarik sebuah rumusan masalah tentang Bagaimana Penerapan Akuntansi Zakat Infaq dan Shodaqoh pada Badan Amil Zakat Nasional (BAZNAS) Provinsi Jawa Barat. Adapun tujuan dari penelitian ini adalah untuk mengetahui bagaimana penerapan akuntansi zakat infaq dan Shodaqoh pada Badan Amil Zakat Nasional (BAZNAS) Provinsi Jawa Barat.

\section{TINJAUAN PUSTAKA \\ Badan Amil Zakat Nasional}

Badan Amil Zakat Nasional (BAZNAS) merupakan badan resmi dan satu satunya yang dibentuk oleh pemerintah berdasarkan Keputusan Presiden RI No. 8 Tahun 2001 yang memiliki tugas dan fungsi menghimpun dan menyalurkan zakat, infaq, dan Shodaqoh (ZIS) pada tingkat nasional (pusat.baznas.go.id). Lahirnya UndangUndang Nomor 23 Tahun 2011 tentang Pengelolaan Zakat semakin mengukuhkan peran
BAZNAS sebagai lembaga yang berwenang melakukan pengelolaan zakat secara nasional. Dalam UU tersebut, BAZNAS dinyatakan sebagai lembaga pemerintah nonstruktural yang bersifat mandiri dan bertanggung jawab kepada Presiden melalui Menteri Agama. Dengan demikian, BAZNAS bersama Pemerintah bertanggung jawab untuk mengawal pengelolaan zakat yang berasaskan: syariat Islam, amanah, kemanfaatan, keadilan, kepastian hukum, terintegrasi dan akuntabilitas.

\section{Lembaga Amil Zakat}

Lembaga Amil Zakat (LAZ) adalah intitusi pengelolaan zakat yang sepenuhnya dibentuk atas prakarsa masyarakat dan oleh masyarakat yang bergerak di bidang da'wah, pendidikan, sosial dan kemaslahatan umat Islam. Lembaga Amil Zakat dikukuhkan, dibina dan dilindung pemerintah. Pengukuhan LAZ dilakukan oleh pemerintah atas usul LAZ yang telah memenuhi persyaratan. Pengukuhan dilaksanakan setelah terlebih dahulu dilakukan penelitian persyaratan. Zakat

Qardawi (1996: 86) menjelaskan bahwa Zakat merupakan sesuatu yang azasi bagi umat islam, karena merupakan pemenuhan rukun islam. Zakat adalah sejumlah harta tertentu yang diwajibkan Allah untuk diserahkan kepada orang-orang yang yang berhak. Dikatakan azasi oleh karena keberadaannya sangat fundamental bagi upaya pencapaian kondisi kehidupan yang lebih baik bagi individu yang berzakat maupun penerima zakat. Bagi individu yang berzakat, hartanya akan bertambah banyak, lebih berarti atau bermakna dan terlindungi dari kebinasaan Qardawi (1996: 34-35). Selain itu jiwa orang yang berzakat akan menjadi bersih, demikian halnya hartanya. Sedangkan bagi penerima zakat tentunya akan bermanfaat untuk menutupi kekurangan sumber penghidupannya dan bahkan kemudian mengangkat martabat diri, keluarga dan masyarakatnya. Syahatah (2004: 5) menyebutkan bahwa Zakat ada dua macam:

1. Zakat maal, yaitu zakat yang diwajibkan atas harta yang memenuhi syaratsyarat tertentu.

2. Zakat badan atau zakat fitrah yaitu zakat yang diwajibkan kepada umat islam pada bulan ramadhan.

\section{Infaq}

Menurut Budiman (2002:4) pengertian infaq merupakan asal kata dari nafaqa yang artinya 
menafkahkan dan membelanjakan bagi orang memberi belanja bagi keluarganya sama artinya dengan memberi nafkah, dan dalam hal memberi belanjanya itu disebut menginfaqkan. Terdapat dua jenis infaq yang pertama, infaq wajib yang terdiri atas zakat dan nasar, yang bentuk dan jumlah pemberiannya telah ditentukan. Nadzar adalah sumpah atau janji untuk melakukan sesuatu di masa yang akan dating. Menurut Qardhawi (1996:37) Nadzar itu adalah sesuatu yang makruh. Namun apabila diucapkan, maka harus dilakukan sepanjang hal itu untuk mendekatkan diri kepada Allah SWT. Kedua, infaq sunnah yakni infaq yang dilakukan seorang muslim untuk mencari ridha Allah, biasa dilakukan dengan berbagai cara dan bentuk. Misalnya memberikan makanan bagi orang yang tetkena bencana.

\section{Shadaqah}

Budiman (2002:5) menjelaskan pengertian shadaqah adalah suatu pemberian yang diberikan oleh seseorang muslim kepada orang lain secara spontan dan sukarela tanpa dibatasi oleh waktu dan jumlah tertentu; suatu pemberian yang diberikan oleh seseorang sebagai suatu kebijakan yang mengharapkan ridha Allah SWT dan pahala semata. Pernyataan Standar Akuntansi 109 (PSAK 109) tentang Akuntansi Zakat dan Infak/Shodaqoh menyatakan bahwa Infak/Shodaqoh menurut PSAK 109 adalah harta yang diberikan secara sukarela oleh pemiliknya, baik yang peruntukannya dibatasi (ditentukan) maupun tidak dibatasi.

Wakaf

Menurut Sudarsono (2007: 259) wakaf diambil dari kata "waqafa", menurut bahasa berarti menahan atau berhenti. Dalam hukum Islam, wakaf berarti menyerahkan suatu hak milik yang tahan lama (zatnya) kepada seseorang atau Nadzir (penjaga wakaf), baik berupa perorangan maupun badan pengelola dengan ketentuan bahwa hasil atau manfaatnya digunakan untuk hal-hal yang sesuai dengann syari'at Islam. Harta yang diwakafkan keluar dari hak milik yang mewakafkan, dan bukan pula menjadi hak milik Nadzir, tetapi menjadi hak milik Allah dalam pengertian hak masyarakat Umum. Menurut Tohirin (2002: 493) Secara umum bentuk wakaf dapat dibedakan kedalam dua kategori antara lain: a. Wakaf untuk manfaat individu dan keluarga yang disebut wakaf keluarga (family waqf).

b. Wakaf untuk kepentingan umum dan kesejahteraan si miskin dan disebut wakaf publik (Public Waqf).

\section{Akuntansi}

Menurut American Accounting Association (AAA) akuntansi adalah proses mengidentifikasi, mengukur, dan melaporkan informasi ekonomi untuk memungkinkan dilakukannya penilaian serta pengambilan keputusan secara jelas dan tegas bagi pihak-pihak yang berkepentingan.

Menurut Pontoh (2013: 2) Akuntansi meliputi 3 (tiga) aktivitas dasar - identifikasi, pencatatan, dan mengkomunikasikan peristiwa ekonomi dari sebuah organisasi kepada para pengguna yang berkepentingan.

\section{Laporan keuangan}

Menurut Kieso (2011:5), laporan keuangan merupakan sarana utama bagi suatu perusahaan untuk mengkomunikasikan informasi keuangannya kepada pihak luar. Laporan ini menyediakan informasi mengenai sejarah perusahaan yang diukur dalam bentuk uang.

\section{Perlakuan Akuntansi}

Tabel 1. Perlakuan Akuntansi

\begin{tabular}{|l|l|l|}
\hline $\begin{array}{l}\text { Pengukuran } \\
\text { (Measurement) }\end{array}$ & $\begin{array}{l}\text { Pengakuan } \\
\text { (Recognition) }\end{array}$ & $\begin{array}{l}\text { Pengungkapan } \\
\text { (Disclosure) }\end{array}$ \\
\hline $\begin{array}{l}\text { Penentuan } \\
\text { jumlah rupiah } \\
\text { objek (kos) yang } \\
\text { dicatat pertama } \\
\text { kali saat terjadi } \\
\text { transaksi }\end{array}$ & $\begin{array}{l}\text { Pencatatan atau } \\
\text { jumlah rupiah } \\
\text { (kos) }\end{array}$ & $\begin{array}{l}\text { Cara pembeberan } \\
\text { melalui statement } \\
\text { keuangan }\end{array}$ \\
\hline
\end{tabular}

Sumber: Suwardjono (2006)

\section{Laporan Keuangan Amil}

Dalam PSAK No. 109 tentang akuntansi zakat, infaq atau Shodaqoh terdapat beberapa komponen laporan keuangan yang harus dibuat oleh amil secara lengkap yang terdiri dari:

1. Neraca (laporan posisi keuangan)

2. Laporan perubahan dana

3. Laporan perubahan aset kelolaan

4. Laporan arus kas

5. Catatan atas laporan keuangan.

\section{METODOLOGI PENELITIAN}




\section{Jenis dan Sumber Data}

Penelitan ini menggunakan data kualitatif. Data kualitatif yang merupakan hasil wawancara yang diperoleh dari pihak Badan Amil Zakat Nasional (BAZNAS) Provinsi Jawa Barat. Sumber data yang diperoleh dalam penelitian ini adalah data sekunder, dimana data yang dikumpulkan adalah berupa gambaran umum, sejarah, visi, misi, program kerja, serta laporan keuangan Badan Amil Zakat Nasional (BAZNAS) Provinsi Jawa Barat.

\section{Metode Analisis}

Penelitian ini merupakan penelitian yang bersifat deskriptif kualitatif dengan tujuan untuk memberikan gambaran yang mendetail tentang latar belakang, sifat-sifat serta karakteristik yang khas dari subjek penelitian.

\section{HASIL DAN PEMBAHASAN}

Hasil Analisis penerapan PSAK 109 pada Badan Amil Zakat Nasional (BAZNAS) Provinsi Jawa Barat

Tabel 2. Analisa Penerapan PSAK 109

\begin{tabular}{|l|l|l|}
\hline PSAK 109 & $\begin{array}{l}\text { Badan Amil Zakat } \\
\text { Nasional (BAZNAS) } \\
\text { Provinsi Jawa Barat }\end{array}$ & $\begin{array}{l}\text { Keses } \\
\text { uaian }\end{array}$ \\
\hline $\begin{array}{l}\text { Pengakuan } \\
\text { penerimaan }\end{array}$ & $\begin{array}{l}\text { Pengakuan penerimaan } \\
\text { Zakat menggunakan } \\
\text { zakat diakui pada saat } \\
\text { kas atau aset lainnya } \\
\text { diterima }\end{array}$ & $\begin{array}{l}\text { Sesuai } \\
\text { mengakui pengaruh } \\
\text { transaksi dan peristiwa }\end{array}$ \\
lainnya pada saat kas & \\
atau yang & \\
$\begin{array}{l}\text { Pengukuran Aset } \\
\text { zakat yang diterima } \\
\text { muzaki diakui sebagai } \\
\text { penambah dana zakat } \\
\text { sebesar jumlah yang } \\
\text { diterima jika dalam } \\
\text { bentuk kas dan sebesar } \\
\text { nilai wajar jika dalam } \\
\text { bentuk non kas }\end{array}$ & $\begin{array}{l}\text { Zakat yang diterima } \\
\text { dicatat sebesar uang } \\
\text { dalam bentuk barang }\end{array}$ & Sesuai \\
sebesar nilai wajar. & \\
\hline
\end{tabular}

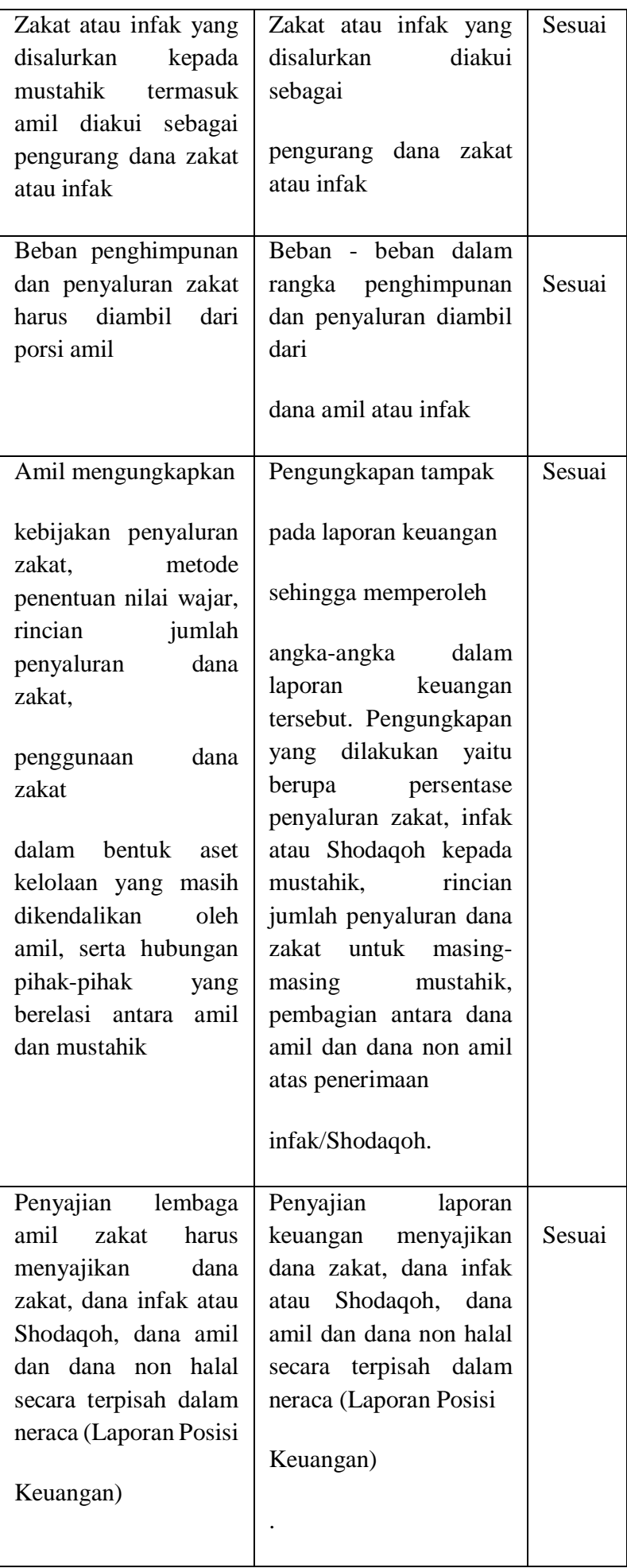

Berdasarkan tabel diatas dapat disimpulkan bahwa laporan keuangan Badan Amil Zakat Nasional (BAZNAS) Provinsi Jawa Barat untuk perlakuan akuntansi mengenai pengakuan 
penerimaan zakat, pengukuran aset zakat yang diterima pengakuan penyaluran zakat dan pengungkapan telah susuai dengan PSAK109.

Pembahasan Analisis penerapan PSAK 109 pada Badan Amil Zakat Nasional (BAZNAS) Provinsi Jawa Barat

Laporan Keuangan BAZNAS Provinsi Jawa Barat tahun 2016 (masih berupa rekapitulasi pengumpulan dan penyaluran saja) diterapkan ke PSAK No. 109 maka akan memperoleh data data sebagai berikut :

Tabel 3

Laporan Penerimaan dan Pendistribusian Zakat, Infaq/Shodaqoh BAZNAS Provinsi Jawa Barat 2017

\begin{tabular}{|c|c|c|c|}
\hline \multicolumn{4}{|c|}{$\begin{array}{l}\text { BADAN AMIL ZAKAT PROVINSI JAWA BARAT } \\
\text { LAPORAN PENERIMAAN \&PENDISTRIBUSIAN } \\
\text { ZAKAT, INFAQ / SHODAQOH } \\
\text { 31 DESEMBER } 2017\end{array}$} \\
\hline 1 & $\begin{array}{l}\text { Saldo awal per } 31 \text { Desember } \\
2016\end{array}$ & Rp $14,999,662,172$ & \\
\hline \multirow[t]{8}{*}{2} & Penerimaan & & \\
\hline & a. Penerimaan Dana Zakat & Rp $15,454,218,650$ & \\
\hline & b. Penerimaan Infaq/Shodaqoh & Rp $\quad 1,207,642,500$ & \\
\hline & $\begin{array}{l}\text { c. Bagi Hasil Bank atas Dana } \\
\text { Zakat }\end{array}$ & & \\
\hline & d. Dana Amil & $\operatorname{Rp} \quad 2,920,859,610$ & \\
\hline & e. Kenaikan Uang Muka & Rp $\quad 776,796,100$ & \\
\hline & $\begin{array}{l}\text { f. Kenaikan Liabilitas Jangka } \\
\text { Panjang }\end{array}$ & $\mathrm{Rp} \quad 532,947,581$ & \\
\hline & $\begin{array}{l}\text { Sub Total Penerimaan + Saldo } \\
\text { Awal }\end{array}$ & Rp $\quad 35,892,126,613$ & \\
\hline \multirow[t]{8}{*}{3} & Pengeluaran & & \\
\hline & a. Pengeluaran Dana Zakat & & $\operatorname{Rp} 23,030,107,665$ \\
\hline & b. Pengeluaran Infaq/Shodaqoh & & Rp $\quad 998,564,454$ \\
\hline & c. Penyaluran Dana Amil & & Rp $3,150,603,928$ \\
\hline & $\begin{array}{l}\text { d. penurunan /investasi Jangka } \\
\text { Pendek }\end{array}$ & & Rp $4,012,896,542$ \\
\hline & e. Penurunan Piutang & & Rp $\quad 156,547,500$ \\
\hline & f. Aktivitas Investasi & & Rp $\quad 446,419,000$ \\
\hline & Sub Total Pengeluaran & & Rp31,795,139,089 \\
\hline 4 & Saldo Per 31 Desember 2017 & & Rp 4,096,987,524 \\
\hline
\end{tabular}

Tabel diatas adalah laporan keuangan BAZNAS Provinsi Jawa Barat yang sudah diolah. Dalam proses penyusunan laporan keuangan BAZNAS Provinsi Jawa Barat tidak terlepas dari proses pengumpulan bukti penerimaan dan penyaluran dana zakat yang kemudian dicatat dalam pencatatan harian. Siklus pencatatan harian dilakukan pada saat terjadi transaksi penerimaan dan penyaluran dana zakat dan infak / Shodaqoh dari para muzakki dan donatur. Pencatatan ini kemudian dibuatkan laporan kas harian selanjutnya dimasukkan ke dalam laporan penerimaan dan penyaluran dana zakat dan infaq, Shodaqoh.

Penerapan Laporan Posisi Keuangan BAZNAS Provinsi Jawa Barat berdasarkan PSAK No.109 


\section{Tabel 4}

Laporan Posisi Keuangan

BAZNAS Provinsi Jawa Barat 2017

\begin{tabular}{|c|c|c|c|c|}
\hline \multicolumn{5}{|c|}{$\begin{array}{l}\text { BADAN AMIL ZAKAT PROVINSI JAWA BARAT } \\
\text { LAPORAN POSISI KEUANGAN } \\
31 \text { DESEMBER } 2017\end{array}$} \\
\hline $\begin{array}{l}\text { Aset } \\
\text { Lancar }\end{array}$ & & Liabilitas & & \\
\hline $\begin{array}{l}\text { Kas dan } \\
\text { Setara Kas }\end{array}$ & Rp $4,096,987,606$ & $\begin{array}{l}\text { Liabilitas } \\
\text { Jangka Pendek }\end{array}$ & & \\
\hline $\begin{array}{l}\text { Investasi } \\
\text { Jangka } \\
\text { Pendek }\end{array}$ & Rp $4,012,896,542$ & $\begin{array}{l}\text { Dana Non } \\
\text { Halal }\end{array}$ & $\mathrm{Rp}$ & $3,734,878$ \\
\hline Piutang & $\mathrm{Rp} \quad 218,900,000$ & Dana Titipan & $\mathrm{Rp}$ & $593,725,802$ \\
\hline $\begin{array}{l}\text { Uang } \\
\text { Muka }\end{array}$ & $\mathrm{Rp} \quad 422,909,000$ & Hutang Pajak & $\mathrm{Rp}$ & 758,762 \\
\hline $\begin{array}{l}\text { Jumlah } \\
\text { Aset } \\
\text { Lancar }\end{array}$ & Rp $8,751,693,148$ & $\begin{array}{l}\text { Jumlah } \\
\text { Liabilitas } \\
\text { Jangka Pendek }\end{array}$ & $\mathrm{Rp}$ & $598,219,442$ \\
\hline $\begin{array}{l}\text { Aset } \\
\text { Tidak } \\
\text { Lancar }\end{array}$ & & Saldo Dana & & \\
\hline $\begin{array}{l}\text { Aset } \\
\text { Tetap- } \\
\text { Nilai } \\
\text { Bersih }\end{array}$ & $\operatorname{Rp} \quad 401,392,381$ & $\begin{array}{l}\text { Saldo Dana } \\
\text { Zakat }\end{array}$ & $\mathrm{Rp}$ & $6,837,629,717$ \\
\hline $\begin{array}{l}\text { Aset } \\
\text { Kelolaan }\end{array}$ & $\mathrm{Rp} \quad 292,931,918$ & $\begin{array}{l}\text { Saldo dana } \\
\text { Infaq / } \\
\text { Shodaqoh }\end{array}$ & $\mathrm{Rp}$ & $883,237,103$ \\
\hline $\begin{array}{l}\text { Total Aset } \\
\text { Tidak } \\
\text { Lancar }\end{array}$ & $694,324,299$ & $\begin{array}{l}\text { Saldo Dana } \\
\text { Amil }\end{array}$ & $\mathrm{Rp}$ & $1,126,931,185$ \\
\hline & & $\begin{array}{l}\text { Jumlah Saldo } \\
\text { Dana }\end{array}$ & $\mathrm{Rp}$ & $8,847,798,005$ \\
\hline $\begin{array}{l}\text { TOTAL } \\
\text { ASET }\end{array}$ & Rp $9,446,017,447$ & $\begin{array}{l}\text { TOTAL } \\
\text { LIABILITAS } \\
\text { DAN SALDO } \\
\text { DANA }\end{array}$ & $\mathbf{R p}$ & $9,446,017,447$ \\
\hline
\end{tabular}

Sumber : Data BAZNAS Prov. Jawa Barat

Berikut penjelasan mengenai laporan perubahan posisi keuangan (neraca) pada BAZNAS Provinsi Jawa Barat berdasarkan PSAK No. 109.

1. Aset

Aset dibagi menjadi dua yaitu aset lancar dan aset tidak lancar. Kas dan setara kas merupakan total dari kas dan setara kas awal tahun 2017 ditambah dengan total kas masuk dikurangi beban operasional pada tahun 2017. Total asset BAZNAS Provinsi Jawa Barat sebesar Rp 9.446.017.447.

2. Liabilitas dan Saldo Dana Berdasarkan pemeriksaan neraca saldo yang ada dan hasil wawancara didapati bahwa BAZNAS Provinsi Jawa Barat memiliki liabilitas sebesar Rp 598,219,442 dan saldo dana sebesar Rp 8,847,798,005 jadi total liabilitas dan saldo dana sebesar 9.446.017.447.

Saldo Dana dari BAZNAS Provinsi Jawa Barat terdiri dari dana zakat, dana infak/Shodaqoh, dan dana amil. Dana zakat adalah bagian nonamil atas penerimaan zakat, misalnya untuk keperluan yang berhubungan dengan zakat dan tidak diperuntukkan pada amil. Dana infak/Shodaqoh adalah bagian nonamil atas penerimaan infak /Shodaqoh, misalnya untuk keperluan hal-hal khusus sesuai permintaan pemberi sumbangan. Dana amil adalah bagian amil atas dana zakat dan infak/Shodaqoh serta dana lain yang oleh pemberi diperuntukkan bagi amil. Dana amil digunakan untuk pengelolaan amil.

Penerapan Laporan Arus Kas BAZNAS Provinsi Jawa Barat berdasarkan PSAK No.109

\section{Tabel 5}

Laporan Arus Kas

31 Desember 2017

\begin{tabular}{|c|c|c|}
\hline \multicolumn{3}{|c|}{$\begin{array}{l}\text { 3ADAN AMIL ZAKAT PROVINSI JAWA BARAT } \\
\text { APORAN ARUS KAS } \\
\text { II DESEMBER } 2017\end{array}$} \\
\hline \multicolumn{3}{|l|}{$\begin{array}{l}\text { IRUS KAS DARI AKTIVITAS } \\
\text { JPERASI }\end{array}$} \\
\hline 'enerimaan Zakat & $\mathrm{Rp}$ & $15,454,218,650$ \\
\hline 'enyaluran Zakat & $-\mathrm{Rp}$ & $23,030,107,665$ \\
\hline $\begin{array}{l}\text { 'enerimaan Infaq / Shodaqoh } \\
\text { erikat }\end{array}$ & \multicolumn{2}{|r|}{$94,560,929$} \\
\hline $\begin{array}{l}\text { 'enerimaan Infaq / Shodaqoh } \\
\text { idak terikat }\end{array}$ & \multicolumn{2}{|c|}{ Rp $\quad 1,113,081,656$} \\
\hline $\begin{array}{l}\text { 'enyaluran Infaq / Shodaqoh } \\
\text { Terikat }\end{array}$ & & $25,985,600$ \\
\hline $\begin{array}{l}\text { 'enyaluran Infaq / Shodaqoh } \\
\text { idak Terikat }\end{array}$ & \multicolumn{2}{|c|}{-Rp $\quad 972,578,854$} \\
\hline $\begin{array}{l}\text { Iak Amil dari Zakat Infak, dan } \\
\text {;umbangan Lainnya }\end{array}$ & \multicolumn{2}{|c|}{ Rp $\quad 2,420,859,610$} \\
\hline 'enerimaan APBD & $\mathrm{Rp}$ & $400,000,000$ \\
\hline 'enerimaan APBN & $\mathrm{Rp}$ & $100,000,000$ \\
\hline 3iaya SDM & $-\mathrm{Rp}$ & $1,554,920,444$ \\
\hline 3eban Sosialisasi Zakat & $-\mathrm{Rp}$ & $672,865,650$ \\
\hline 3eban Operasional Rutin & $-\mathrm{Rp}$ & $422,817,952$ \\
\hline 'enyaluran Dana APBD & $-\mathrm{Rp}$ & $399,999,882$ \\
\hline enyaluran Dana APBN & $-\mathrm{Rp}$ & $100,000,000$ \\
\hline Penempatan)/Pencairan Deposito & & - \\
\hline $\begin{array}{l}\text { Kenaikan)/Penurunan Investasi } \\
\text { angka Pendek }\end{array}$ & $-\mathrm{Rp}$ & $4,012,896,542$ \\
\hline Kenaikan)/Penurunan Piutang & $-\mathrm{Rp}$ & $156,547,500$ \\
\hline $\begin{array}{l}\text { Kenaikan)/Penurunan Uang } \\
\text { Muka }\end{array}$ & $\mathrm{Rp}$ & $776,796,100$ \\
\hline $\begin{array}{l}\text { Kenaikan / (Penurunan) Liabilitas } \\
\text { angka Pendek }\end{array}$ & $\mathrm{Rp}$ & $532,947,581$ \\
\hline $\begin{array}{l}\text { Kas bersih yang diperoleh dari } \\
\text { lktivitas operasi }\end{array}$ & $-\mathrm{Rp}$ & $10,404,284,363$ \\
\hline $\begin{array}{l}\text { IRUS KAS DARI AKTIVITAS } \\
\text { NVESTASI }\end{array}$ & & \\
\hline 'erolehan Aset Tetap & $-\mathrm{Rp}$ & $311,089,000$ \\
\hline 'erolehan Aset Kelolaan & $-\mathrm{Rp}$ & $135,330,000$ \\
\hline $\begin{array}{l}\text { Kas bersih yang digunakan } \\
\text { mtuk aktivitas investasi }\end{array}$ & $-\mathrm{Rp}$ & $446,419,000$ \\
\hline $\begin{array}{l}\text { IRUS KAS DARI AKTIVITAS } \\
\text { 'ENDANAAN } \\
\end{array}$ & & \\
\hline $\begin{array}{l}\text { Kenaikan (Penurunan) Bersih } \\
\text { Kas dan Setara Kas }\end{array}$ & $-R p$ & $10,902,674,562$ \\
\hline $\begin{array}{l}\text {;aldo Kas dan Setara Kas Awal } \\
\text { 'eriode }\end{array}$ & $\mathrm{Rp}$ & $14,999,662,172$ \\
\hline $\begin{array}{l}\text {;aldo Kas Setara Kas Akhir } \\
\text { 'eriode }\end{array}$ & $\mathrm{Rp}$ & $4,096,987,610$ \\
\hline
\end{tabular}


1. Arus Kas dari Aktivitas Operasi : akun-akun yang disajikan adalah penambahan dan pengurangan arus kas yang terjadi pada perkiraan yang terkait dengan operasional BAZNAS Provinsi Jawa Barat seperti penerimaan (zakat, Shodaqoh/infaq, hak amil, APBD, APBN), penyaluran zakat, infaq/Shodaqoh, penyaluran dana APBD, penyaluran dana APBN, biaya SDM, beban sosialisasi zakat, beban operasional, kenaikan atau penurunan investasi jangka pendek, kenaikan atau penurunan piutang, kenaikan atau penurunan uang muka, dan kenaikan atau penurunan liabilitas jangka pendek.

2. Arus Kas dari Aktivitas investasi : akun-akun yang termasuk dalam perkiraan ini adalah semua perolehan / penerimaan dan pengeluaran yang terkait dengan investasi BAZNAS Provinsi Jawa Barat, seperti perolehan asset tetap dan perolehan asset kelolaaan.

3. Arus Kas dari Aktivitas Pendanaan: perkiraan yang termasuk dalam aktivitas pendanaan adalah perkiraan penerimaan dari aktivitas pencarian dana. BAZNAS Provinsi Jawa Barat, pada tahun 2017 tidak terjadi aktivitas pendanaan.

\section{Penerapan Catatan Atas Laporan Keuangan BAZNAS Provinsi Jawa Barat berdasarkan PSAK No.109}

\section{Tabel 6. Catatan Atas Laporan Keuangan}

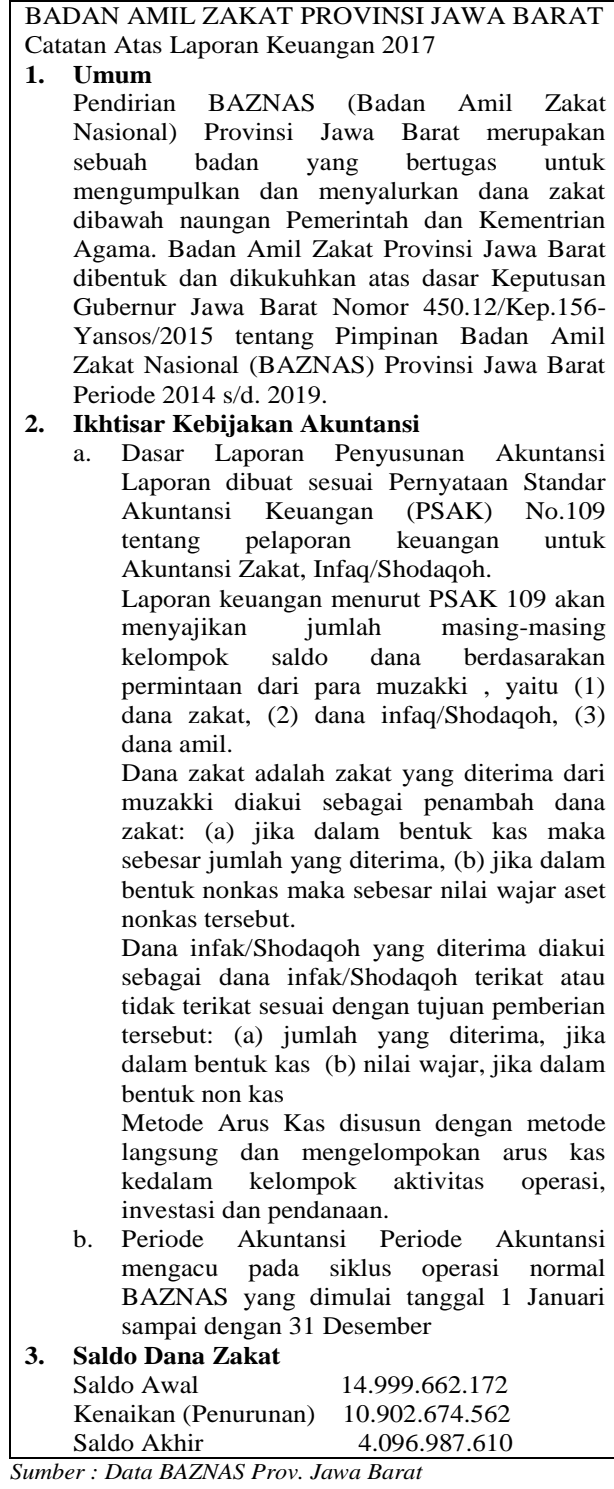

2. Ikhtisar Kebijakan Akuntansi

a. Dasar Laporan Penyusunan Akuntansi Laporan dibuat sesuai Pernyataan Standar Akuntansi Keuangan (PSAK) No.109 tentang pelaporan keuangan untuk Akuntansi Zakat, Infaq/Shodaqoh.

Laporan keuangan menurut PSAK 109 akan menyajikan jumlah masing-masing kelompok saldo dana berdasarakan permintaan dari para muzakki, yaitu (1) dana zakat, (2) dana infaq/Shodaqoh, (3) dana amil.

Dana zakat adalah zakat yang diterima dari muzakki diakui sebagai penambah dana zakat: (a) jika dalam bentuk kas maka sebesar jumlah yang diterima, (b) jika dalam bentuk nonkas maka sebesar nilai wajar aset nonkas tersebut.

Dana infak/Shodaqoh yang diterima diakui sebagai dana infak/Shodaqoh terikat atau tidak terikat sesuai dengan tujuan pemberian tersebut: (a) jumlah yang diterima, jika dalam bentuk kas (b) nilai wajar, jika dalam bentuk non kas

Metode Arus Kas disusun dengan metode langsung dan mengelompokan arus kas kedalam kelompok aktivitas operasi, investasi dan pendanaan.

b. Periode Akuntansi Periode Akuntansi mengacu pada siklus operasi normal BAZNAS yang dimulai tanggal 1 Januari sampai dengan 31 Desember

3. Saldo Dana Zakat

Saldo Awal

Kenaikan (Penurunan) 10.902 .674 .562

Saldo Akhir 4.096.987.610

Sumber : Data BAZNAS Prov. Jawa Barat

\section{KESIMPULAN}

Berdasarkan hasil penelitian dan pembahasan mengenai penerapan Pernyataan Standar 
Akuntansi Keuangan No.109 di BAZNAS Provinsi Jawa Barat, maka diperoleh beberapa kesimpulan sebagai berikut.

1. BAZNAS Provinsi Jawa Barat menyajikan laporan keuangannya sesuai dengan peruntukan dananya yaitu meliputi laporan kas umum (zakat), laporan kas infaq/Shodaqoh, laporan kas dana amil, dan laporan kas aset kelolaan.

2. Akuntansi zakat yang diterapkan oleh BAZNAS mengenai pengakuan penerimaan zakat, pengukuran asset zakat, zakat/infak yang disalurkan serta pengungkapan kebijakan transaksi zakat/infak telah sesuai dengan PSAK 109.

3. BAZNAS Provinsi Jawa Barat dalam menyajikan laporan keuangan sesuai dengan format yang ditentukan oleh IAI, sehingga laporan keuangan BAZNAS Provinsi Jawa Barat berkualitas dan bermanfaat bagi masyarakat.

\section{Saran}

Berdasarkan kesimpulan dari penelitian ini, maka saran dalam penerapan Pernyataan Standar Akuntansi Keuangan No.109 di BAZNAS Provinsi Jawa Barat adalah sebagai berikut.

1. BAZNAS Provinsi Jawa Barat selalu mempertahankan kualitas dalam penyajian laporan keuangan sesuai dengan PSAK 109 dengan format yang telah ditentukan oleh IAI sehingga memberikan manfaat dalam hal membangun kepercayaan mayarakat kepada pihak BAZNAS.

2. BAZNAS Provinsi Jawa Barat sebaiknya melakukan sosialisasi kepada masyarakat tentang pentingnya menyalurkan dana zakat infaq/shodaqoh kepada lembaga pemerintah.

3. BAZNAS Provinsi Jawa Barat sebaiknya memperkenalkan program programnya kepada masyarakat, agar pengumpulan dana zakat, infaq / shodaqoh dapat dioptimalkan untuk kepentingan ummat.

\section{DAFTAR PUSTAKA}

Alfarizi, Salman, 2017. Analisis Penerapan Akuntansi Zakat dan Infak/Shodaqoh (PSAK 109) pada Lembaga Kemanusiaan Nasional Pos Keadilan Peduli Ummat Cabang Kendari. Skripsi S1. UNHAS, Makassar.

Budiman, Budi. 2002. Potensi Dana ZIS Sebagai Instrumen Ekonomi Islam; Dari Teori dan Implementasi manajemennya. Proceeding Simposium Nasional 1 Ekonomi Islam. Yogyakarta: P3EIFEUII.

Ikatan Akuntan Indonesia. PSAK 109 : Akuntansi Zakat dan Infaq/Shodaqoh. Efektif 2017

Istutik, 2013. Analisi Implementasi Akuntansi Zakat dan Infak/Shodaqoh (PSAK:109) Pada Lembaga Amil Zakat di Kota Malang. Jurnal Akuntansi Akrual, Vol.2, No.1, Hal : 19-24

Kieso, Donald E, Jerry j. Weygant dan Terry D. Warfield. 2002. Akuntansi Intermediate edisi kesepuluh. Jakarta: Erlangga

Kholifah, Siti, 2015. Analisis Kesesuaian Penerpan Pernyataan Standar Akuntansi Keuangan No.109 Mengenai Penyajian Laporan Keuangan Dana ZIS. Skripsi S1. UIN Syarif Hidayatullah, Jakarta

Mamang Sangadji, Etta dan Sopiah, 2010. Metodologi Penelitian, Penerbit Andi, Yogyakarta

Nurhayati, Sri dan Wasilah, 2013. Akuntansi Syariah Di Indonesia. Salemba Empat, Edisi 3, Jakarta.

Shahnaz Sabrina, 2016. Penerapan PSAK No.109 Tentang Pelaporan Keuangan Akuntansi Zakat, Infaq/Shodaqoh pada BASAZ Provinsi Sulawesi Utara. Jurnal Berkah Ilmiah Efisiensi. Vol.16, No.1, Hal : $1-10$. 
Sudarsono, Heri. 2003. Bank dan Lembaga Keuangan Syari'ah; Deskripsi dan Ilustrasi,Edisi2. Yogyakarta: Ekonisia.

Suwardjono. 2006. Teori Akuntansi; Perekayasaan Pelaporan Keuangan; Edisi Ketiga. Yogyakarta: BPFE

Syahatah, Husayn. 2004. Akuntansi Zakat; Panduan Praktis Penghitungan Zakat Kontemporer. Jakarta: Pustaka Progressif.

Tohirin, Achmad. 2002. Konstribusi Pengembangan Wakaf (Tunai) Di Indonesia. Proceeding Simposium Nasional 1 Ekonomi Islam. Yogyakarta: P3EIFEUII.

Qardawi, Yusuf. 1996. Hukum Zakat studi

komparatif mengenai status dan filsafat zakat

berdasarkan Qur'an dan Hadist. Bogor:

Pustaka Litera Antar Nusa/ Pustaka Mizan 